\title{
US satellite laws under scrutiny
}

\author{
NASA allegations muddy waters as government recommends reforms to technology-trade rules.
}

\section{BY SHARON WEINBERGER}

A dvocates of international trade and collaboration in space technology thought that they were making headway against rules that restrict both in the name of US security. But on the same day that the US government released a longawaited report that recommends easing those regulations, allegations surfaced that a NASA director may have broken the rules when he gave foreign nationals access to an agency research facility. It is not yet clear whether the allegations will strengthen the case for preserving current restrictions.

The allegations were brought by unnamed whistle-blowers to US Senator Charles Grassley (Iowa), the ranking Republican member of the Senate Committee on the Judiciary, who asked about the accusations in a letter to NASA administrator Charles Bolden on 18 April. At issue is whether Simon 'Pete' Worden, director of the NASA Ames Research Center in Moffett Field, California, gave foreign citizens access to information that falls under the International Traffic in Arms Regulations (ITAR), a set of rules that aims to prevent the transfer of potentially strategic technologies to foreign countries. Critics have long complained that ITAR unduly hampers US companies that seek to export satellite technology; it has also created hurdles for academic and government research institutions - including NASA Ames - that have collaborators in friendly nations such as the United Kingdom and Canada.

Grassley's office told Nature that NASA is investigating the allegations; an agency spokesman confirmed that NASA has referred Grassley's query to its inspectorgeneral, but declined to comment further. Whatever the outcome, the case is sure to feed a debate reanimated by an 18 April report in which the US Department of Defense and Department of State recommend pulling many non-military communications and remotesensing satellites out of ITAR's jurisdiction.

Advocates of export-control reform say that the report is the first encouraging development since 1998, when Congress placed all spacecraft and related equipment under ITAR, following revelations that two US companies had shared technical information about a launch failure with China, without seeking government approval. The move proved a blow to many US satellite firms, which lost international customers who were unwilling to deal with the licensing rules. Universities with

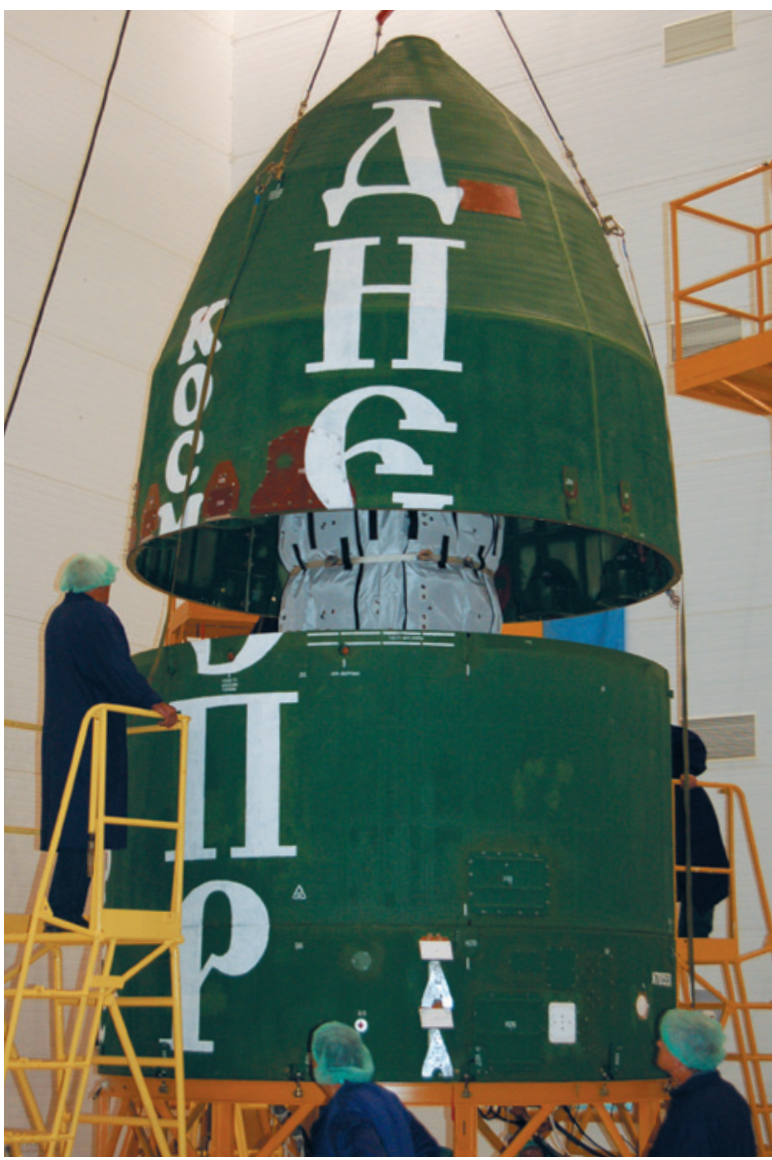

US company Bigelow Aerospace was subject to rigorous export controls when it launched Genesis 1 on a Ukrainian rocket.

recalls the legal hoops that the company had to jump through to use a simple stand to hold its Genesis 1 experimental space habitat before the habitat was sent into orbit on a Ukrainian rocket. "This stand was metal, round and had four legs," says Gold. "Flip it upside down, put a tablecloth on it, and it was indistinguishable from a coffee table."

To ease such pressures, the report from the defence and state departments urges Congress to shift oversight of many commercial satellites and related activities from the state department, which currently administers ITAR, to the commerce department, where it resided before 1998 .

"I think that careful implementation of this report's recommendations may have the potential to reduce some of the unintended consequences of space export control on universities and university education," says Kevin Schmadel, vice-president for government relations at the Universities Space Research Association, based in Columbia, Maryland.

But Gold does not think that the recommendations will be put into practice swiftly. "There are hurdles to overcome, and whether the report is enough to build momentum is a question yet to be resolved," he says. Some lawmakers are likely to oppose any efforts to change the rules, citing national security. Last year, a bill that would have moved regulation of communications satellites back to the commerce department was introduced in the US House of Representatives, but it has not moved forward. And the NASA Ames case could influence opinion, potentially providing a rea-

foreign students are also subject to the rules, which cover what can be taught in classes and who can work on satellite-related student projects funded by the government.

Anecdotes abound about the detrimental impact of ITAR. In one case, detailed by the American Association of Universities in Washington DC, a Chinese postdoctoral student at a US university needed a licence to view NASA's comments on software developed for the agency's Gravity Probe B project - even though he had written the software himself. And Michael Gold, director of operations in Washington DC for Bigelow Aerospace, a space-technology company based in North Las Vegas, Nevada, son not to ease export controls.

Attempts to change ITAR may have to wait until next year, when they could be tacked on to a bill authorizing spending by the defence department. Joel Johnson, an analyst with the Teal Group, an aerospace and defence consulting firm based in Fairfax, Virginia, has long followed the debate over export controls. He says that with federal elections coming up in November, it is unlikely that Republicans in Congress would want to grant a victory on ITAR to President Barack Obama's administration. "I would be surprised, quite frankly, if anything happens before the election," says Johnson. . 